\title{
Entrepreneurial Education and Training for Architects
}

\author{
By Christo Vosloo*
}

\begin{abstract}
Sustained design excellence for an architect depends on the establishment of a structured, focused and well-managed architectural firm to support the architectural designer. Unfortunately Entrepreneurial Education and Training (EET) does not receive due attention in architectural programmes at universities, architectural conferences and in architectural publications. Because of this, many architects wrongly believe that good work is enough to ensure a consistent flow of good clients and a strong practice. As a result many architects are struggling to get their practices off the ground and the profession as a whole is losing stature and respect. It has been shown that firms started as a result of an entrepreneurial disposition will have a better chance of success than those started out of necessity, as many architects' firms are. The result is that firms accept work which is not adequately remunerated, preventing them from reaching a strong negotiating position - one that could potentially allow them the agency to turn away clients whose only aim is shortterm profit. Ultimately the quality of the built environment suffers. This paper will consider some EET models and how these could be applied to architectural education and training before suggesting how the entrepreneurial orientation resulting from such education and training could be applied in the establishment of a new architects' firm.
\end{abstract}

\section{Introduction}

David Littlefield stated that "Too many architects make too bad a living, a problem that is largely the result of believing that quality design will inevitably lead to decent clients and a fair income. The truth is that the business dimension of an architectural practice is no less important than producing the drawings".

Architects' firms, like all businesses, must be started and managed in ways that will increase their chances of profitability and survival. ${ }^{2}$ Since 1920 the American Institute of Architects (AIA) has recognised the need for, and published guidance on, the business and administrative dimensions of

${ }^{*}$ Associate Professor, University of Johannesburg, Republic of South Africa.

1. David Littlefield, The architect's guide to running a firm (Oxford: Elsevier/Architectural Press, 2005), 5.

2. Elena Marcheso Moreno, "Starting an Architecture Firm," in The architect's handbook of professional practice $\left(14^{\text {th }}\right.$ Edition), ed. J. A. Demkin (New Jersey: John Wiley \& Sons, 2008). 
architects' firms. ${ }^{3}$ In 1962 the Royal Institute of British Architects (RIBA) found a need for a greater awareness amongst architects of the importance of the business side of an architects' firm and published guidelines in this regard. ${ }^{4}$ Over time a number of books and journal articles on this topic have appeared by the AIA (2008), Chappell and Willis (1992), Davis (2008), Littlefield (2005), Piven and Perkins (2003) and Ostine et al (2010), amongst others. Despite this, business and entrepreneurial training still does not regularly feature in architectural journals or at architectural conferences. ${ }^{5}$

The aim of this paper is to highlight the need for Entrepreneurial Education and Training (EET) and the role EET can play in changing the way in which architects start new firms, to look at EET models that might be appropriate for architects, and to show the decisions and options facing architects who have acquired an entrepreneurial mind-set through EET during the process of establishing a new firm.

The research methodology followed for this paper was that of a literature review. Boote and Beile state that, "A thorough, sophisticated literature review is the foundation and inspiration for substantial, useful research". 6 Many authors agree that literature reviews function as a very important step in qualitative, quantitative and mixed methods research processes.

The scope of this article does not allow for a comprehensive review of models or for any in depth review of models described in this paper. The models selected form part of the author's $\mathrm{PhD}$ study into a Framework for Entrepreneurship Education, Training and Support for South African Architects at the University of Pretoria.

3. American Institute of Architects, The architect's handbook of professional practice (14 ${ }^{\text {th }}$ Edition), ed. J. A. Demkin (New Jersey: John Wiley \& Sons, 2008).

4. Nigel Ostine, David Stanford, Graham Hickson-Smith, Richard Fairhead and John Waddell, Architect's handbook of practice management $\left(8^{\text {th }}\right.$ edition) (London: RIBA Publications, 2010).

5. Christo Vosloo, "Establishing viable architectural firms," Architecture South Africa 72 (May/June 2015).

6. David N. Boote and Penny Beile, "Scholars before researchers: On the centrality of the dissertation literature review in research preparation," Educational Researcher 34, no. 6 (2005), 5 .

7. Jullie P. Combs, Rebecca M. Bustamante and Anthony J. Onwuegbuzie, “A mixed methods approach to conducting literature reviews for stress and coping researchers: An interactive literature review process framework," in Toward a broader understanding of stress and coping: Mixed methods approaches, ed. G. S. Gates, W. H. Gmelch and M. Wolverton (Series Eds.) \& K. M. T. Collins, A. J. Onwuegbuzie and Q. G. Jiao, The Research on Stress and Coping in Education Series (Vol. 5) (Charlotte, NC: Information Age, 2010) 213-241; Anthony J., Onwuegbuzie, Kathleen M. T. Collins, Nancy L. Leech, Amy B. Dellinger and Qun G. Jiao, "A meta-framework for conducting mixed research syntheses for stress and coping researchers and beyond," in Toward a broader understanding of stress and coping: Mixed methods approaches, ed. G. S. Gates, W. H. Gmelch and M. Wolverton (Series Eds.) \& K .M. T. Collins, A. J. Onwuegbuzie and Q. G. Jiao (Vol. Eds.), The Research on Stress and Coping in Education Series (Vol. 5) (Charlotte, NC: Information Age, 2010), 169-211. 


\section{Entrepreneurial Education and Training}

Vaerio, Parton and Robb explain that EET consists of academic education or formal training programmes aimed at equipping individuals with the entrepreneurial mind-sets and skills that will encourage and support participation and improve performance in a range of entrepreneurial and associated managerial activities. ${ }^{8}$ Generally, research has shown that businesses started by persons with an entrepreneurial mind-set and orientation are opportunity based and hence outperform those started out of necessity. ${ }^{9}$

There is currently substantial interest in entrepreneurship and its potential role in actualising the economic and social development goals of governments. These goals include growth, innovation, employment and equity. ${ }^{10}$ It is also acknowledged that entrepreneurial awareness can have a variety of wider beneficial spill-overs. This includes an increased understanding of business amongst employees. Such an increased understanding can enhance the performance of people who work inside established businesses, thereby improving the entrepreneurial performance of the companies they work for. ${ }^{11}$

Many authors such as McClelland (1986), Hisrich, Peters and Shepherd (2005), Kuratko and Hodgetts (2007), and Birley \& Muzyka (2000), have identified a range of traits that can be associated with high levels of entrepreneurial performance According to Botha (2014:31) these traits include confidence, perseverance and determination, high energy levels, resourcefulness, ability to take calculated risks, creativity and innovation, dynamism, leadership, commitment, need for independence, positive response to challenges, internal locus of control, toleration of ambiguity and need for achievement. $^{12}$

Wickham and other authors hold that an entrepreneurial mind-set or orientation is something that can be acquired. ${ }^{13}$ Valerio et al agree, but on condition that education and training programmes include both creative and entrepreneurial skills. ${ }^{14}$ It would thus appear that while a range of traits, skills and attitudes are required in entrepreneurship, many aspects can be taught.

8. Alexandria Valerio, Brent Parton and Alicia Robb, Entrepreneurship education and training programmes around the world: dimensions for success (Washington: World Bank, 2014).

9. Natasha Turton and Mike Herrington, Global entrepreneurship monitor, 2012: South African report (Cape Town: The UCT Centre for Innovation and Entrepreneurship, Graduate School of Business, University of Cape Town, 2012).

10. Valerio, Parton and Robb, Entrepreneurship education and training programmes around the world: dimensions for success.

11. Inna Kozlinska, Fundamental view of the outcomes of Entrepreneurial Education (Centre for Entrepreneurship, Faculty of Economics and Business Administration, University of Tartu, 2012).

12. Melodi Botha, "The entrepreneur," in Entrepreneurship; a South African perspective, ed. G. Nieman and C. Nieuwenhuizen (Pretoria: Van Schaik, 2014), 29-51.

13. Phillip A. Wickham, Strategic entrepreneurship ( $4^{\text {th }}$ Edition) (Harlow: Prentice Hall/Pearson Education, 2006).

14. Valerio, Parton and Robb, Entrepreneurship education and training programmes around the world: dimensions for success. 
Human beings are individuals and many already have certain innate skills that can assist them in becoming entrepreneurs. EET can lead to the acquisition of missing skills and develop innate skills. How then can entrepreneurial development be fostered through EET?

Maasdorp and Van Vuuren devised the model illustrated in Figure 1. ${ }^{15}$ According to the authors this model demonstrates the environmental factors that influence the entrepreneurial activity of nations. According to this model, entrepreneurial activity in a country is firstly affected by the extent to which a population has an appropriate entrepreneurial mind-set or entrepreneurial orientation because this is critical to the survival and growth of businesses, which in turn influences the economic welfare of nations. It also is a prerequisite for entrepreneurial activity. National entrepreneurial mind-set is stimulated by a range of factors including culture, family and role models, work experience, personal entrepreneurial orientation, education quality and education levels. ${ }^{16}$ Thus EET that develops entrepreneurial awareness amongst the wider population can influence the national entrepreneurial mind-set. It can also develop the required skills and traits amongst those who choose to become entrepreneurs.

A supportive environment (one that provides support and establishes a climate conducive to entrepreneurial activity) is the next requirement. This indicates the need for a developed physical and business infrastructure and a deregulated legal environment that can provide opportunity and not stifle initiative. It also implies the availability of a range of business development services that can provide training and financing. ${ }^{17}$ To meet this requirement, persons in government must have a measure of entrepreneurial understanding and appreciation. Therefore, appropriate general EET can assist in the creation of a supportive environment.

Lastly it will require the appropriate cooperative environment. This necessitates organisations and institutions that are actively involved in promoting entrepreneurship and supporting and developing entrepreneurs with advice, research and capacity building. These organisations should encourage entrepreneurship and develop entrepreneurial orientation at the societal level. EET, once again, can play a very important role in this regard. ${ }^{18}$

15. E. F. de V. Maasdorp and Juri Van Vuuren, "Entrepreneurship," in Business Management ( $2^{\text {nd }}$ edition) (Pretoria: Van Schaik, 1998), 694-725.

16. Cecile Nieuwenhuizen, The Nature and Development of Entrepreneurship, in Entrepreneurship: a South African perspective ( $3^{\text {rd }}$ edition), ed. G. Nieman and C. Nieuwenhuizen (Pretoria: Van Schaik, 2014), 3-22.

17. Ibid.

18. Ibid. 


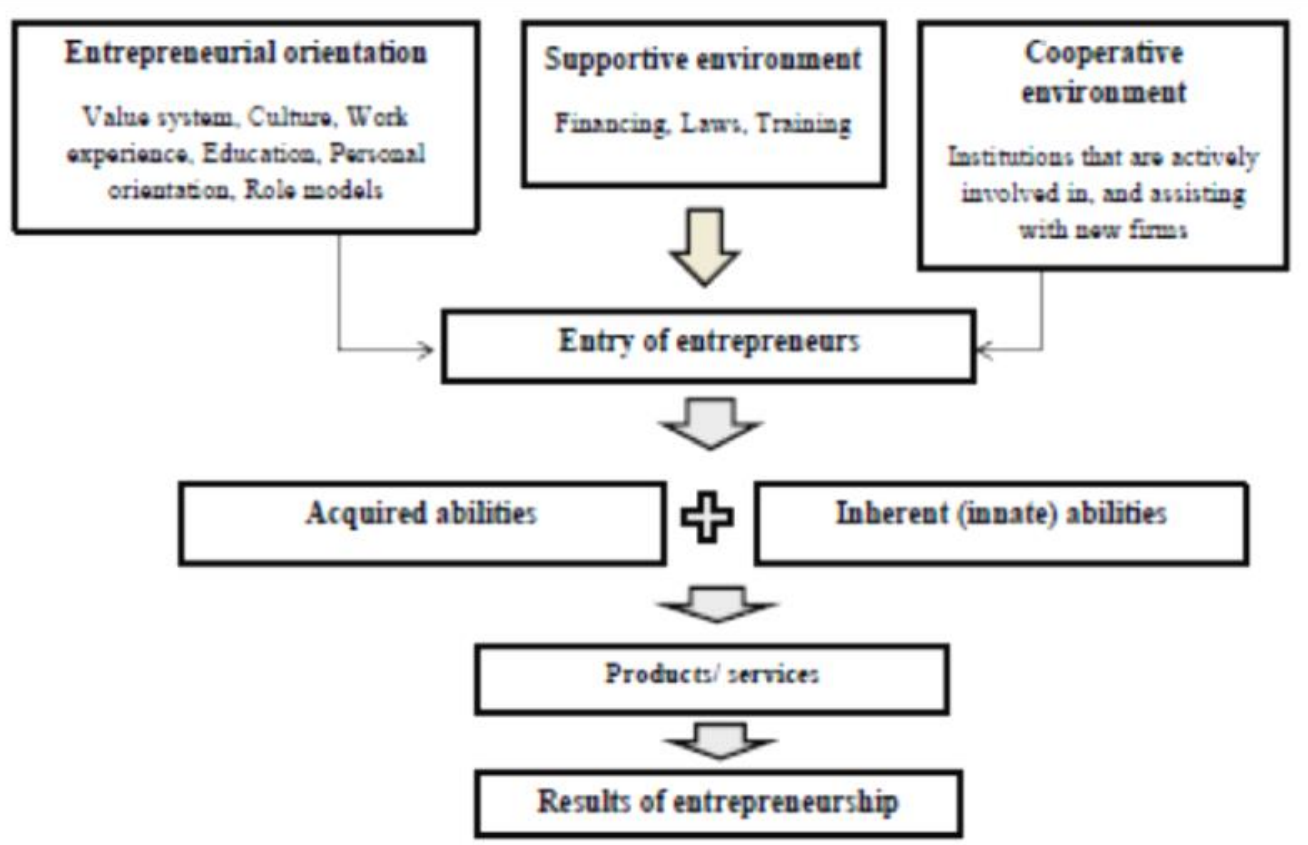

Figure 1. A Model for Entrepreneurship Development

Source: E.F. de V. Maasdorp, and J. J. Van Vuuren, "Entrepreneurship," in Business Management (2nd edition), (1998), 721.

This model highlights the need for EET and support at various levels in society and with different aims. In summary, appropriate EET for architects can develop entrepreneurial mind-sets, develop innate entrepreneurial traits ${ }^{19}$ in architects, allow architects to acquire the abilities and knowledge they do not have and lead to an environment and support system that will make it easier to successfully establish and grow an architects' firm.

\section{Entrepreneurial Education and Training Frameworks}

The need for EET and proposed EET frameworks has set off a vibrant scientific discourse. Various frameworks and models have been developed and proposed. Three such models have been selected for review in terms of EET theory and on the basis of their possible application to architectural EET. Currently the Conceptual Framework developed by Valerio et al represents the most comprehensive framework for the development or evaluation of EET programmes. ${ }^{20}$ This framework is illustrated in Figure 2.

This framework is illustrated in Figure 2.

19. Robin Th'ng, “A question of character: just how entrepreneurial are architects?” RIBA Journal (April 2005): ii-iv. Th'ng (2005) found that most architects possess the majority of the innate skills associated with entrepreneurs but that some aspects need development.

20. Valerio, Parton and Robb, Entrepreneurship education and training programmes around the world: dimensions for success. 


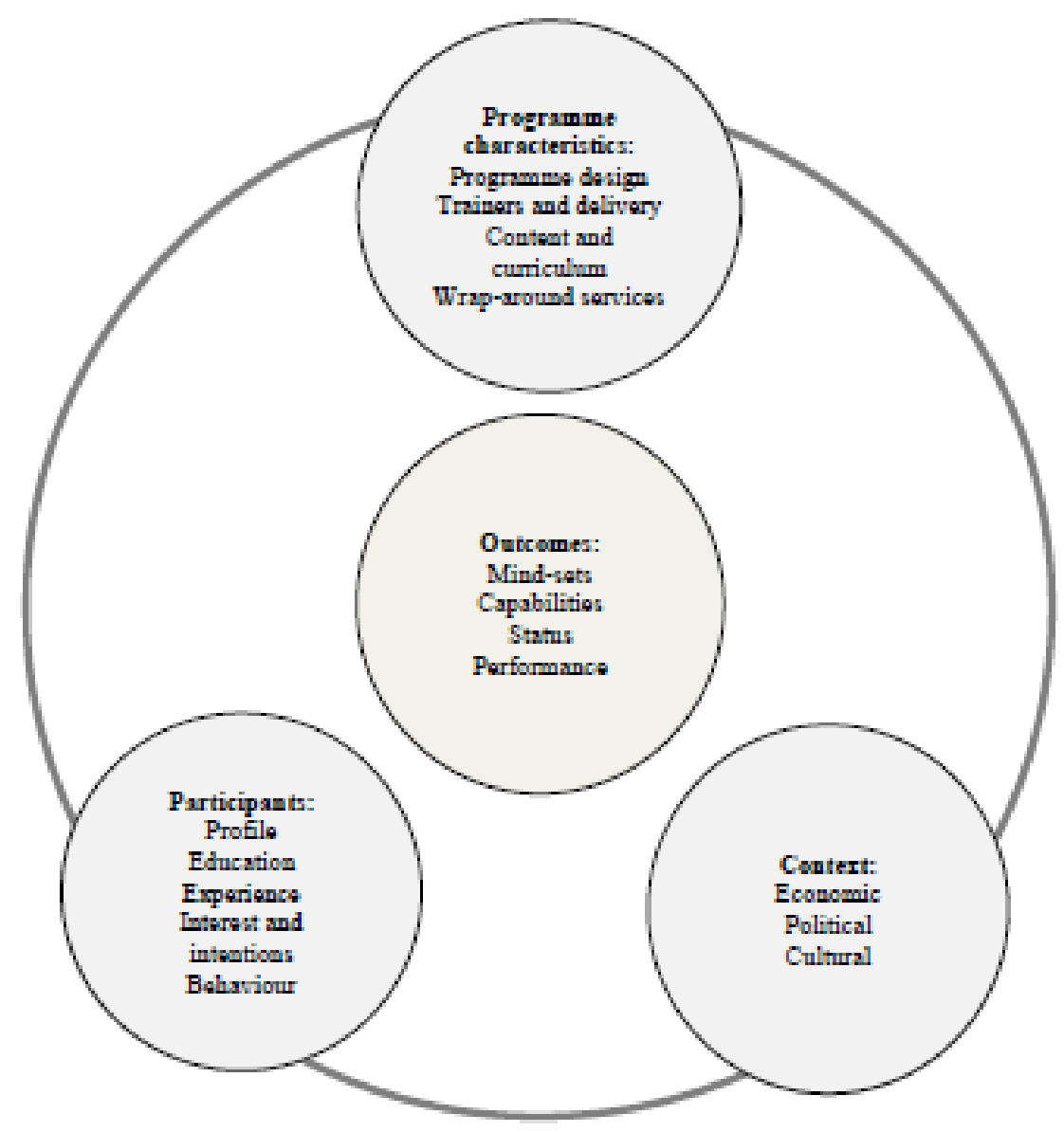

Source: Valerio et al., Entrepreneurship education and training programmes around the world: dimensions for success (2014), 24.

The Valerio et al framework indicates that EET programmes and models must be evaluated in terms of its programme characteristics, outcomes, participant profile and context. This framework will be used to evaluate the three selected models and to suggest how they might be implemented.

'Programme characteristics' comprise programme design, trainers (or facilitators) and methods of delivery, content and curriculum and the inclusion of any "wrap-around-services" such as ongoing mentoring. 'Participants' comprises the profile, education, experience, interests, intensions and behaviour of the attendees. 'Context' refers to the economic, political and cultural environment that applies to the particular offering while 'Outcomes' refers to the changes the offering hopes to, or might, effect on the participant's mind-sets, status, capabilities and performance.

The first model to be considered is the model to educate for entrepreneurial performance, proposed by Pretorius, Nieman and van Vuuren: ${ }^{21}$

21. Marius Pretorius, Gideon Nieman and Jurie Van Vuuren, "Critical evaluation of two models for entrepreneurial education: an improved model through integration," International Journal of Educational Management 19, no. 5 (2005). 


\section{$E$ for $E / P=f[a F \times b M(c E / S \times d B / S) \times(e A+f B / P)]$}

In this model, $E$ for $E / P$ is education for enhanced entrepreneurial performance; $\mathrm{F}$ refers to the facilitator's ability, skills and experience; $M$ is for motivation; $E / S$ is for entrepreneurial skills; $\mathrm{B} / \mathrm{S}$ refers to business skills and knowledge; $A$ is for approaches to learning; $B / P$ is for business plan utilisation and approach.

According to this model "Education for entrepreneurial performance... is a linear function of the facilitator's ability and skills... to enhance motivation... entrepreneurial skills... and business skills... through the creative use of different approaches... and specifically the business plan". ${ }^{22}$ The main shortcoming of this model, as acknowledged by the authors, is that it does not recognise the importance of the context of the programme. Other weaknesses identified include that the preparedness level or previous experience of learners are not explicitly taken into account. ${ }^{23}$ Many other noted authors on EET such as Cope (2005) will also question the stated position that entrepreneurial learning is a linear process. However, one of the model's strongest attributes is its recognition of the crucial role played by the facilitator whose skills to explain, enthuse, initiate discussion, cite examples and knowledge of the architectural profession will greatly influence the achievement of the outcomes.

Implementing this model within the architectural environment can be done as follow:

\section{Participants}

Because the model aims at enhancing entrepreneurial performance the participants should be practicing or employed architects who already have their own firms or intend starting their own firms within the near future.

Programme Characteristics

Programme design: The programme might comprise lectures and workshops supplemented by practical exercises offered to qualified architects who already have their own firms or are about to start their own firms.

Trainers (or facilitators): The facilitator will in addition to unique facilitating abilities, also need to have a deep understanding of the nature of architects' business and knowledge related to entrepreneurship and business management.

Delivery: The participants will be practicing or employed architects who will not be able to attend programmes that will remove them from their firms for a significant period of time. Delivery should thus be through after-hours sessions or could be via online platforms including webinars.

22. Pretorius, Nieman and Van Vuuren, Critical evaluation of two models for entrepreneurial education: an improved model through integration, 415.

23. Marius Pretorius and Thomasz Wlodarczyk, "Entrepreneurial training curriculum assessment: the case of new venture creation learnerships," SAJEMS NS 10, no. 4 (2007). 
Content and curriculum: The participants will have high levels of professional/technical skills but (in most cases) limited business and entrepreneurial skills, implying a strong focus on business and strategic skills.

"Wrap-around-services": The model does not include any supplementary services such as mentoring or advice but such services could be added.

\section{Context}

While the model does not specifically allow for this, the context that must be allowed for are that the learners will be qualified architects who either already have their own firms or are about to start their own firms. The programme must comprise architectural practice and the unique opportunities and challenges associated with it, country or region specific regulation and requirements, economic systems, attitudes towards entrepreneurship and support services available.

\section{Outcomes}

The outcomes sought would be to improve the entrepreneurial performance and hence the prospects and status of the individuals and firms involved.

Because of the pivotal role of the facilitator it will require someone who, in addition to unique facilitator's abilities, also need to have a deep understanding of the nature of architects' business. This implies a special person with scarce skills. It also does not include any "wrap-around services". Furthermore, because of its narrow focus on enhancing entrepreneurial performance, it will not enhance entrepreneurial knowledge and awareness amongst general architectural staff. This shortcoming will limit the potential benefits EET can have for an architects' firm. These aspects will limit the model's applicability to the architectural profession.

The second model from Kunene holds that an EET programme must provide certain additional skills that successful entrepreneurs require because they will enhance the performance of their businesses. ${ }^{24}$ Hence:

\section{Training for $\uparrow E / P=$ training in key skills $\times[1+$ training in supportive skills]}

According to this model the skills required can be divided into key skills and supporting skills. Key skills are those skills that, when absent, would prevent any meaningful performance. Supporting skills describe additive skills, the absence of which would not completely paralyse the business but will impair performance. These include general management skills, computer literacy, building and maintaining human relations, networking, planning,

24. Thandeka Ruth Kunene, "A critical analysis of entrepreneurial and business skills in SMEs in the textile and clothing industry in Johannesburg, South Africa" (PhD thesis, University of Pretoria, 2008), 265. 
creativity, innovation, role-model interpretation, calculated risk-taking, conducting research and development, business systems management and communication skills. Key skills refer to motivation, opportunity recognition, the ability to gather resources, financial management, human resource management, marketing and technical skills. ${ }^{25}$ These are skills that are critical to the success of all firms and should thus be included in any EET programme. Like the previous model discussed this model seeks to enhance entrepreneurial performance. Thus, implementation of this model would require a programme very similar to that described above, and hence it would face the same challenges and restrictions.

Kozlinska ${ }^{26}$ proposed a model that draws a distinction between "Education about entrepreneurship"; general education that comprises general knowledge with low applicability aiming to increase awareness about entrepreneurship in the general population; and "Education for Entrepreneurship" which aims to prepare persons for careers as entrepreneurs by motivating entrepreneurship ("know why") and teaching the skills required ("know what" and "know how") (refer to Figure 3).

Fitting this model to the architectural education and training context will not be simple. Because of the emphasis placed on design, theory and construction related subjects, most architectural programmes at university will not be able to accommodate anything more than a limited overview to both spheres of EET. In addition there could be initiatives to encourage students to think creatively particularly in relation to possible roles for architects in society. Because of this, and in pursuance of the need to create greater awareness of entrepreneurship in society at large, ${ }^{27}$ 'Education about entrepreneurship' should primarily take place at secondary school level. In this case the programme might comprise the following:

\section{Programme Characteristics}

Programme design: The programme might comprise lectures and workshops supplemented by practical exercises offered to secondary school learners.

Trainers (or facilitators): The facilitator will be a secondary school teacher.

Delivery: Delivery will be determined by the general format of the school's programme but could comprise lectures and practical exercises. Entrepreneurial role models could be used to offer additional impact and to lead supportive discussions with the learners.

Content and curriculum: The main aim of the offering would be to increase awareness of entrepreneurship, to create an interest in entrepreneurship and to change attitudes towards entrepreneurship.

25. Vosloo, "Establishing viable architectural firms."

26. Ina Kozlinska, "Contemporary approaches to Entrepreneurship Education," Journal of Business Management 4 (2011), 210.

27. Maasdorp and Van Vuuren, "Entrepreneurship." 
“Wrap-around-services”: At this level 'wrap-around-services' would not be required.

\section{Context}

The particular context will vary from country to country due to differing national attitudes towards entrepreneurs, entrepreneurship and the exposure learners have to entrepreneurs in their immediate environments.

\section{Outcomes}

The outcomes sought would be to enhance the attitude and orientation the learners have towards entrepreneurship and to stimulate learners to start thinking about starting their own businesses rather than planning a career as an employee.

For the reason stated previously "Education for Entrepreneurship" should then take place after graduating with the professional degree, preferably at a relevant the point during the careers of these architects, such as when they have gathered enough experience to be able to start their own firms. In this case the programmes should take on characteristics very similar to that of the first two models.

While this model will facilitate a wider appreciation of entrepreneurship amongst all architects, it still has major limitations. Literature on EET suggest that experiential learning or action learning - learning by doing and reflecting on the experiences encountered - with mentoring, should, because of its benefits, also play a major role in any EET framework. ${ }^{28}$

Hence a major shortcoming of this model is that it, like the previous models, does not make any allowances for "wrap-around services", such as mentoring, during which experienced practitioners can offer advice and guidance to the new incumbent within a formalised relationship. Similarly, none of the models discussed includes training and support from organisations that provide funding and other forms of support to entrepreneurs, which is set as a requirement for entrepreneurial development by Maasdorp and Van Vuuren. $^{29}$

28. Jeffry A. Timmons, and Stephen Spinelli, New venture creation: entrepreneurship for the $21^{\text {st }}$ Century ( $7^{\text {th }}$ edition) (New York: McGraw-Hill Education, 2007); Pretorius, Nieman and Van Vuuren, Critical evaluation of two models for entrepreneurial education: an improved model through integration; Luke Pittaway and Richard Thorpe, "A framework for entrepreneurial learning: A tribute to Jason Cope," Entrepreneurship and Regional Development 24, no. 9-10 (2012); Jason Cope, "Toward a dynamic learning perspective of entrepreneurship," Entrepreneurship Theory and Practice 29, no. 4 (2005).

29. Maasdorp and Van Vuuren, "Entrepreneurship." 

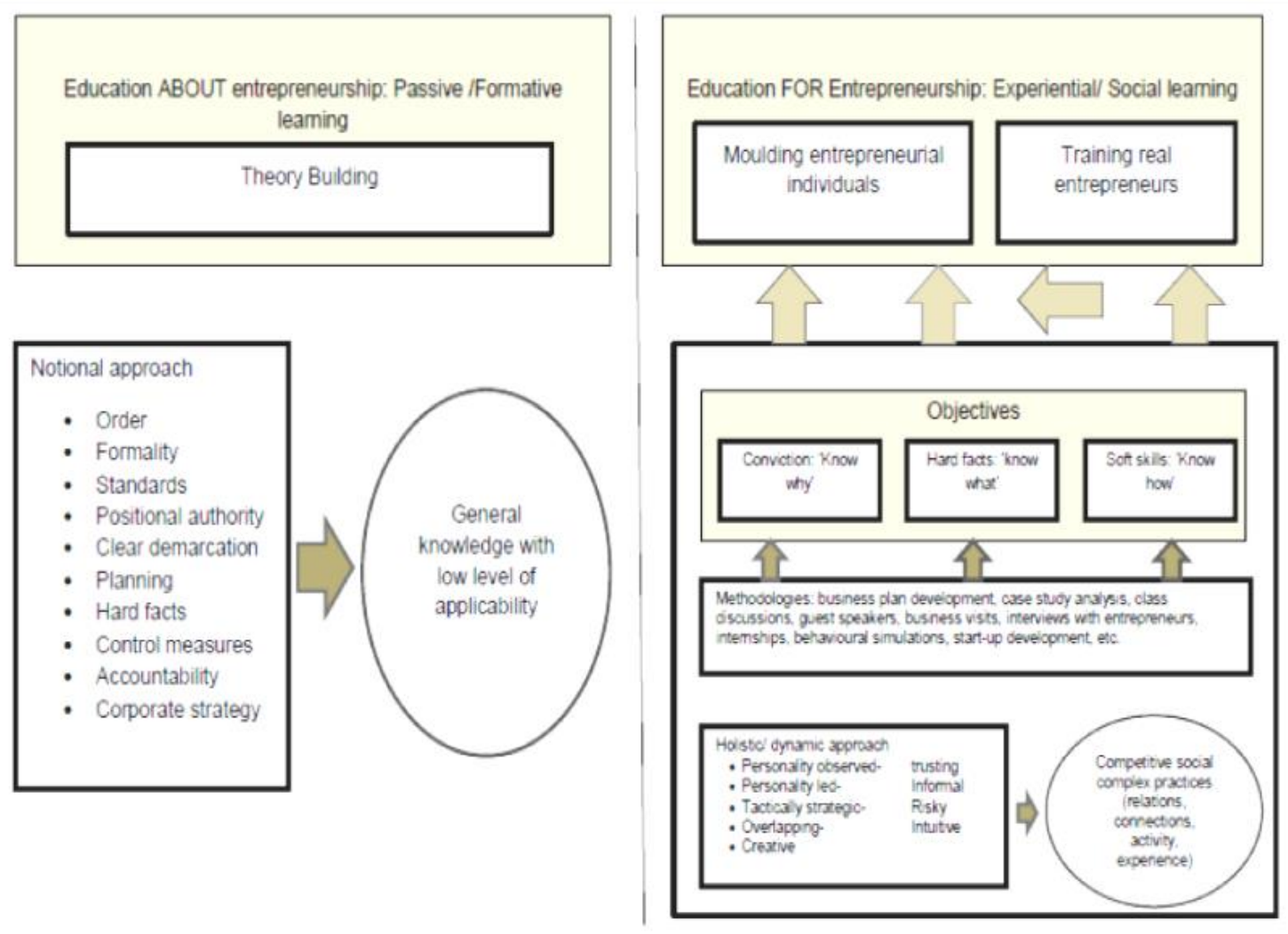

Figure 3. Education about Entrepreneurship versus Education for Entrepreneurship

Source: Kozlinska, "Contemporary approaches to Entrepreneurship Education" (2011), 210.

\section{Establishing a New Firm Using Entrepreneurial Guidelines}

The founding partners of architects' firms are entrepreneurs who are similar to other small business owners. Most founders of architects' firms look to receive reasonable reward and the opportunity for design expression. They do so for a variety of reasons including the associated independence, life-style, and to work with other like-minded individuals. For most architects, success constitutes professional respect, producing interesting buildings, and earning an adequate income. ${ }^{30}$ This does not mean that they are not entrepreneurial.

Because of the currently limited EET available to architects, many architects do not have the background that can guide them in the process of starting and building a firm that can endure the challenges associated with architectural practice. ${ }^{31}$ An appropriate EET programme will lead to more

30. Rena M. Klein, The architect's guide to small firm management: making chaos work for your small firm (Hoboken: John Wiley \& Sons, 2010).

31. Vosloo, "Establishing viable architectural firms." 
architects with an entrepreneurial mind-set who will start new firms by following the normal entrepreneurial process which comprises: ${ }^{32}$

- Firstly identifying a viable opportunity.

- Thereafter applying ingenuity and creativity in conceptualising something that can effectively take advantage of the identified opportunity.

- Finding the resources needed for the conceptualised enterprise.

- Starting and establishing the new enterprise.

- Managing the enterprise.

- Accepting risk.

- Reaping the anticipated reward.

Architects with an entrepreneurial mind-set will be aware of the advantages associated with opportunity-driven entrepreneurial ventures. They will know that opportunity recognition and starting a firm in response to an identified viable opportunity is essential for the enduring success of the firm. ${ }^{33}$ A gap that has been left in the market by those who currently serve it constitutes such an opportunity. ${ }^{34}$ However, Timmons and Spinelli warn that a suitable opportunity is not simply an idea; it must be also be attractive, durable, timely, and call for a service that creates or adds value for the client. ${ }^{35}$ It must also correlate with the founders' own professional strengths and ambitions. The high levels of creativity associated with architectural professionals should assist architects in the process of identifying exploitable opportunities. ${ }^{36}$

Responding to an opportunity is not enough to ensure a viable firm. The firm must be conceptualised in a way that will differentiate and distinguish it from other firms and to adopt an appropriate competitive position. ${ }^{37}$ There are at least six archetypes that the architectural entrepreneur could consider. ${ }^{38}$ These are to become:

- Innovators.

- Project type specialists.

- Extended service providers.

- Community development specialists.

- Project Management experts.

- Cost and quality specialists.

32. Gideon Nieman, "The entrepreneurial process," in Business management: a value chain approach ( ${ }^{\text {nd }}$ Edition), ed. G. Nieman and A. Bennet (Pretoria: Van Schaik, 2006), 4963.

33. Vosloo, "Establishing viable architectural firms."

34. Nieuwenhuizen, The Nature and Development of Entrepreneurship.

35. Timmons and Spinelli, New venture creation: entrepreneurship for the $21^{\text {st }}$ Century.

36. Vosloo, "Establishing viable architectural firms."

37. Ibid.

38. Jack Reigle, "Firm, Identity and Expertise," in The architect's handbook of professional practice ( $14^{\text {th }}$ Edition), ed. J. A. Demkin (New Jersey: John Wiley \& Sons, 2008). 
In addition to the above, the architectural entrepreneur should have learnt that, according to Wickham, ${ }^{39}$ the following competitive approaches can attract work:

- Providing a new product or service.

- Offering increased value.

- Creating new relationships.

- Being flexible.

- Being highly responsive to the client's needs and requirements.

The entrepreneurial architect will then consider and adopt a competitive strategy. Figure 4 depicts the "Strategy Clock" 40 which can act as a guide in this process. ${ }^{41}$ According to the authors, there are eight possible competitive strategies to choose between. Strategies can be based on price or differentiation based on "perceived product or service benefits".

The first strategy is the "no frills" strategy; providing simple, basic products or services at low price. This will require high levels of efficiency, mass production and repetition. The second strategy option is that of "low price". Here the products or services offered have higher perceived benefit levels but are still produced at low cost. This strategy carries the danger of low income margins and competition from others who might be possible to produce the same product but at an even lower cost. Hence efficiency and mass production remains imperative, but now with increased perceived qualityrelated pressures. The "hybrid" strategy will see an increase in perceived value or benefits but with an increase in associated costs. The increase in perceived benefits requires that more attention is focussed on the quality of the product or service but still at low cost. This requires increased expertise and a greater differentiation of product or service. Another step-up is the "differentiation" strategy. Here increased perceived value and uniqueness based on expertise allows the producer of the product or service to have the option of charging more. The above highlights the benefits to architects of offering a differentiated service providing them the opportunity to charge premium fees. This strategy can be extended further by adopting a "focussed differentiation" strategy. Here the producer of the product or service can use their superior experience and expertise to create highly differentiated products and services with higher profit margins.

39. Wickham, Strategic entrepreneurship.

40. Gerry Johnson, Kevan Scholes and Richard Whittington, Exploring corporate strategy $\left(8^{\text {th }}\right.$ Edition) (Harlow: Pearson Education, 2008).

41. This diagram broadly corresponds with Klein's "Business model matrix" (Figure 6) and should be read together. 


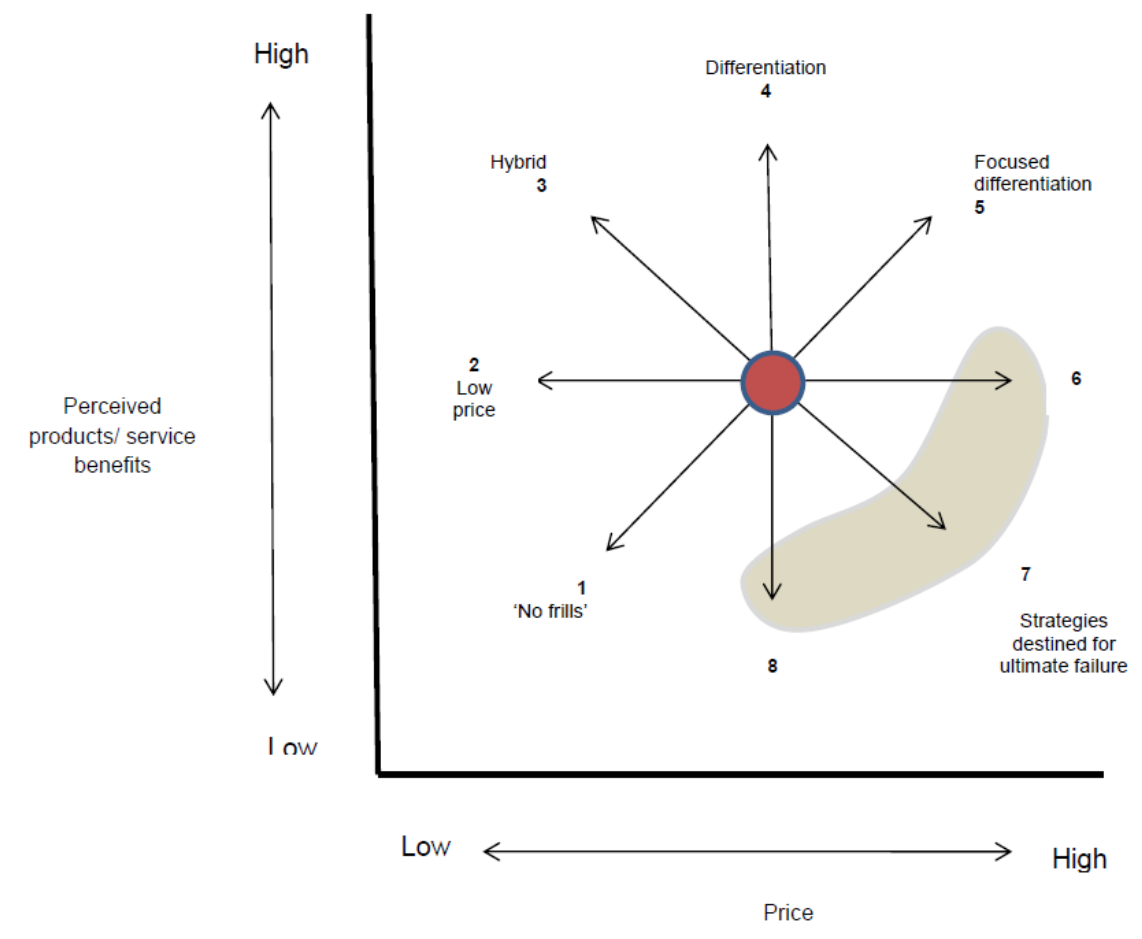

Needs/ risks

1. 'No frills'

2. Low price

3. Hybrid

4. Differentiation

- Without price premium

- With price premium

5. Focused differentiation

7. Increased price/ low value

8. Low value/ standard price
Likely to be segment specific

Risk of price war and low margins: need to be cost leader

Low cost base and reinvestment in low price and differentiation

Perceived added value by user, yielding market share benefits

Perceived added value sufficient to bear price premium

Perceived added value to a particular segment, warranting price premium

Only feasible in monopoly situation

Loss of market share

Figure 4. The Strategy Clock: Competitive Strategy Options

Source: Johnson et al, Exploring corporate strategy (2008), 225.

The final three strategy options, all of which are likely to fail, are to charge increased prices for standard value, increased prices for products of low perceived value, or even to produce products or services of low perceived value while charging standard prices.

Architects with an entrepreneurial mind-set should, throughout this process, keep in mind the following ten essential principles: ${ }^{42}$

42. Andy Pressman, Professional firm 101 (New York: John Wiley \& Sons, 1997). 
- To have a clear vision and create a long-term plan that will get them there.

- To develop and use a network of 'contacts'.

- Build and maintain relationships.

- Control firm overhead costs.

- Make a commitment to using technology.

- Get the best possible advice from those already in the field.

- Find a way to differentiate the firm.

- Understand the clients' values.

- Keep stakeholders updated about developments in the firm, its work and achievements.

- Maintain balance in their lives.

A new architects' firm will have to be designed like a new building: it must respond to its context. ${ }^{43}$ The firm's context comprises the needs, preferences and strengths of its owners, its geographic and economic environment and the opportunity it is responding to. ${ }^{44}$ Furthermore it should be aligned to the preferences, competitive approaches, strategies and models decided on by its founders. Depending on the above, the firm's organisation could be flexible and unconventional, or more structured and conventional. Bigger firms, like bigger buildings, are more complex to manage and hence require a more rigorous structure. ${ }^{45}$ Small firms are simpler in nature and can adopt one or a blend of business models that will be described in the next paragraphs.

Klein $^{46}$ and Kaderlan ${ }^{47}$ suggest that there are three basic firm types that founders of architectural firms can choose between. The first option (refer to Figure 5) is the efficiency-based firm. These firms focus on similar or standardised projects, usually for clients who seek a product rather than a service. This type of firm's structure is relatively formal, centralised and organised to be stable and focused on delivery of relatively conventional designs. Because of its nature, the type of work produced by this type of firm implies standard processes and the re-use of standardised project elements and routine work. ${ }^{48}$ Hence this type of firm would employ relatively more junior staff and fewer senior staff. This type of firm would not offer much by way of satisfaction but could be very profitable.

43. Klein, The architect's guide to small firm management.

44. Vosloo, "Establishing viable architectural firms."

45. Klein, The architect's guide to small firm management.

46. Ibid.

47. Norman Kaderlan, Designing your firm: a principal's guide to creating and managing a design firm (New York: McGraw-Hill, 1991).

48. Vosloo, "Establishing viable architectural firms." 


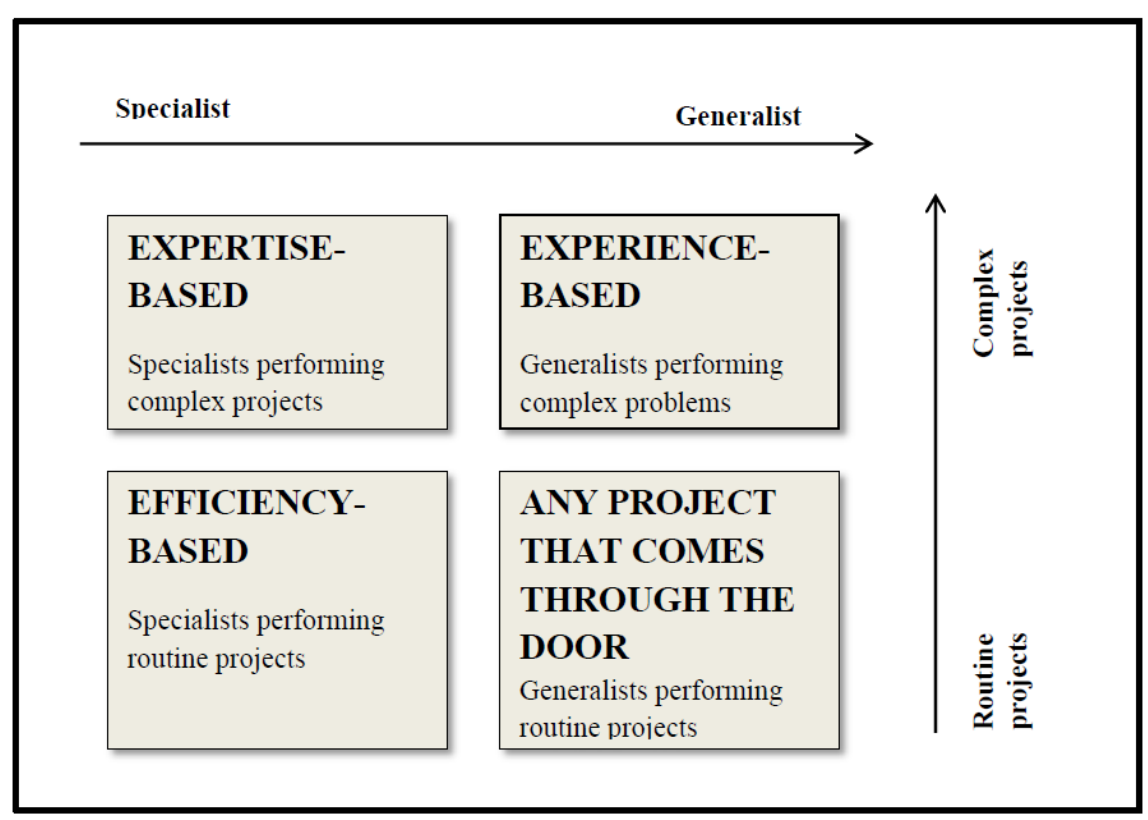

Figure 5. Business Model Matrix

Source: Klein, The architect's guide to small firm management (2010), 13.

The expertise-based firm ${ }^{49}$ or 'strong idea' type firm ${ }^{50}$ is a second type of firm that can be considered. As the name suggests, this type of firm would be configured for innovation. Firms of this type will strive to produce innovative design solutions to unique, complex and challenging, problems. They will focus on new, novel or innovative ideas and will be expertise based. Logically, firms of this type should also adopt a highly flexible, adaptable and informal structure functioning in a dynamic and flexible environment. The firm will perform non-routine designs and hence would comprise senior and talented staff: this implies more partners and project architectural professionals and fewer assistants. This points to higher salary expenses. Because of this, profitability depends on being able to charge high fees for the unique designs rendered. This type of firm could provide great satisfaction and profits but the unpredictable nature of such projects might also lead to financial losses. ${ }^{51}$

A third option could see a firm organised with a focus on experience with a view to providing unique designs that will meet a client's unique needs. Firms of this type can be described as 'strong service' firms. ${ }^{52}$ This firm type must be organised to deliver designs based on experience on complex projects. Because of the highly complex projects they deal with, firms of this type require a flexible structure. This type of firm could provide increased satisfaction and higher profits. However, profitability depends on wellmanaged projects and timeous completion. This will require skilful

49. Klein, The architect's guide to small firm management.

50. Kaderlan, Designing your firm.

51. Vosloo, "Establishing viable architectural firms."

52. Kaderlan, Designing your firm. 
management of staff and other resources. ${ }^{53}$ By implication this indicates a mixture of tasks and staffing levels but with relatively more senior staff and fewer assistants.

The 'anything that comes through the door' type is very common and often results from the absence of an entrepreneurial mind-set and accordingly a lack of planning. ${ }^{54}$ Thus it is something that, unlike the previous options, often does not happen by choice but by default or through entrepreneurial ignorance. Where this results from a conscious choice, these firms are built using a 'business model' that will accept whatever comes their way. Unfortunately, these firms are unfocused and without strategic advantage. This leaves them vulnerable to sudden changes in the socio-economic environment. However, they might survive and even do well in the short term because of the wide, generalised knowledge they have built up over time. However, the generalised focus limits the expertise and experience the firm builds up and will need in order to attract and perform complex, rewarding and more challenging projects. Their lack of focus or intentionality means that these firms only survive on the back of their limited core competencies, personal connections and/or the interests of the firm's founders or leaders. Because of this, they flounder as soon as the prevailing situation changes. Firms of this type also fail to build up any real asset value. ${ }^{55}$

'Multi-specialisation' on the other hand, is an alternative core business strategy where bigger firms with an entrepreneurial orientation look for diversity in their support base by specialising in a few selected project types. ${ }^{56}$ Firms purposefully adopt this strategy in order to limit their exposure to the risks associated with a restricted client-base but while not losing focus as is the case with the aforementioned 'anything that comes through the door' type.

Figure 5 illustrates the relationship between the different firm types or business models and how they relate in terms of specialisation and capacity to do complex projects.

Because change is a constant, firms have to revisit decisions taken from time to time for a variety of reasons as they move through their lifecycles. Regular strategic review and planning must be undertaken. This might indicate a change of strategy or the need for a new business model. Over time, growth and other changes, such as new technology or shifts in the client requirements, might require that the firm be "reinvented" and restructured to accommodate change. ${ }^{57}$ EET will provide the architect/entrepreneur with the ability to perform such strategic reviews and, if necessary, to adopt the required changes.

53. Klein, The architect's guide to small firm management.

54. Ibid.

55. Ibid.

56. Jim Morgan, Management for the small design firm; handling your practice, personnel, finances and projects (New York: Whitney, 1998).

57. Klein, The architect's guide to small firm management. 


\section{Conclusions}

Many architects' firms have been established, and have grown beyond most definitions of small- or even medium-sized businesses, with limited specialised entrepreneurial or business managerial training or guidance available. However, it is not known whether the founders of the world's big firms managed to achieve this because of innate skills, or to what extent they underwent some form of EET of their own accord. What it does imply is that an entrepreneurial mind-set and skills can assist in establishing and growing a firm that can endure. Practicing architecture is a complex undertaking and the range of pressures that firms are subjected to is diverse and substantial. EET should assist architects to follow processes and take decisions that can result in a more robust 'package' within which the architect can practice his or her art. There is still no guarantee of survival or success (by whatever definition), but without the basis of a properly planned, structured and managed business model it is difficult to grow and sustain an architectural firm.

\section{Bibliography}

American Institute of Architects. The architect's handbook of professional practice (14 $4^{\text {th }}$ Edition), edited by JA Demkin. New Jersey: John Wiley \& Sons, 2008.

Birley, Sue and Daniel Muzyka. Mastering entrepreneurship. London: Pearson Education, 2000.

Boote, David N. and Penny Beile. "Scholars before researchers: On the centrality of the dissertation literature review in research preparation." Educational Researcher, 34, no. 6 (2005): 3-15. doi:10.3102/0013189X034006003.

Botha, Melodi. "The entrepreneur." In Entrepreneurship; a South African perspective, 29-51. Edited by G. Nieman and C. Nieuwenhuizen. Pretoria: Van Schaik, 2014.

Chappell, David and Andrew Willis. The architect in practice $\left(7^{\text {th }}\right.$ edition). Oxford: Blackwell Scientific, 1992.

Combs, Jullie P., Rebecca M. Bustamante and Anthony J. Onwuegbuzie. "A mixed methods approach to conducting literature reviews for stress and coping researchers: An interactive literature review process framework." In Toward a broader understanding of stress and coping: Mixed methods approaches, 213241. Edited by G. S. Gates, W. H. Gmelch and M. Wolverton (Series Eds.) \& K. M. T. Collins, A. J. Onwuegbuzie and Q. G. Jiao. The Research on Stress and Coping in Education Series (Vol. 5). Charlotte, NC: Information Age, 2010.

Cope, Jason. "Toward a dynamic learning perspective of entrepreneurship." Entrepreneurship Theory and Practice, 29, no. 4 (2005): 373-397.

Davis Clark S. "Architectural services and compensation." In The architect's handbook of professional practice $\left(14^{\text {th }}\right.$ Edition). Edited by J. A. Demkin. New Jersey: John Wiley \& Sons, 2008.

Hisrich, Robert D., Michael P. Peters and Dean A. Shepherd. Entrepreneurship (6 $^{\text {th }}$ Edition). New York: McGraw-Hill/Irwin, 2005.

Johnson, Gerry, Kevan Scholes and Richard Whittington. Exploring corporate strategy $\left(8^{\text {th }}\right.$ Edition $)$. Harlow: Pearson Education, 2008.

Kaderlan, Norman. Designing your firm: a principal's guide to creating and managing a design firm. New York: McGraw-Hill, 1991. 
Klein, Rena M. The architect's guide to small firm management: making chaos work for your small firm. Hoboken: John Wiley \& Sons, 2010.

Kozlinska, Inna. "Contemporary approaches to Entrepreneurship Education." Journal of Business Management, 4 (2011): 205-220.

Kozlinska, Inna. Fundamental view of the outcomes of Entrepreneurial Education. Centre for Entrepreneurship. Faculty of Economics and Business Administration. University of Tartu, 2012.

Kunene, Thandeka Ruth. "A critical analysis of entrepreneurial and business skills in SMEs in the textile and clothing industry in Johannesburg, South Africa." PhD thesis. University of Pretoria, 2008.

Kuratko, Donald F. and Richard M. Hodgetts. Entrepreneurship: theory, process and practice. Ohio: South Western, Thomson, 2007.

Littlefield, David. The architect's guide to running a firm. Oxford: Elsevier/Architectural Press, 2005.

Maasdorp, E. F. de V. and Juri Van Vuuren. "Entrepreneurship." In Business Management ( $2^{\text {nd }}$ edition), 694-725. Pretoria: Van Schaik, 1998.

McClelland, David C. "Characteristics of successful entrepreneurs." Journal of Creative Behavior, 2, no. 3 (1986): 219-233.

Moreno, Elena Marcheso. "Starting an Architecture Firm." In The architect's handbook of professional practice ( $14^{\text {th }}$ Edition). Edited by J. A. Demkin, 82-92. New Jersey: John Wiley \& Sons, 2008.

Morgan, Jim. Management for the small design firm; handling your practice, personnel, finances and projects. New York: Whitney, 1998.

Nieman, Gideon. "The entrepreneurial process." In Business management: a value chain approach ( $2^{\text {nd }}$ Edition), 49-63. Edited by G. Nieman and A. Bennet. Pretoria: Van Schaik, 2006.

Nieuwenhuizen, Cecile. "The Nature and Development of Entrepreneurship." In Entrepreneurship: a South African perspective ( $3^{\text {rd }}$ edition), 3-22. Edited by G. Nieman and C. Nieuwenhuizen. Pretoria: Van Schaik, 2014.

Onwuegbuzie, Anthony J., Kathleen M. T. Collins, Nancy L. Leech, Amy B. Dellinger and Qun G. Jiao. "A meta-framework for conducting mixed research syntheses for stress and coping researchers and beyond." In Toward a broader understanding of stress and coping: Mixed methods approaches, 169-211. Edited by G. S. Gates, W. H. Gmelch and M. Wolverton (Series Eds.) \& K. M. T. Collins, A. J. Onwuegbuzie and Q. G. Jiao (Vol. Eds.). The Research on Stress and Coping in Education Series (Vol. 5). Charlotte, NC: Information Age, 2010.

Ostine, Nigel, David Stanford, Graham Hickson-Smith, Richard Fairhead and John Waddell. Architect's handbook of practice management ( $8^{\text {th }}$ edition). London: RIBA Publications, 2010.

Pittaway, Luke and Richard Thorpe. "A framework for entrepreneurial learning: A tribute to Jason Cope." Entrepreneurship and Regional Development, 24, no. 910 (2012): 837-859.

Piven, Peter and Bradford Perkins. Architect's essentials of starting a design firm. New York: John Wiley \& Sons, 2003.

Pressman, Andy. Professional firm 101. New York: John Wiley \& Sons, 1997.

Pretorius, Marius, Gideon Nieman and Jurie Van Vuuren. "Critical evaluation of two models for entrepreneurial education: an improved model through integration." International Journal of Educational Management, 19, no. 5 (2005): 413- 427.

Pretorius, Marius and Thomasz Wlodarczyk. "Entrepreneurial training curriculum assessment: the case of new venture creation learnerships." SAJEMS NS, 10, no. 4 (2007): 504-529. 
Reigle, Jack. "Firm Identity and Expertise." In The architect's handbook of professional practice ( $14^{\text {th }}$ Edition). Edited by J. A. Demkin. New Jersey: John Wiley \& Sons, 2008.

Th'ng, Robin. "A question of character: just how entrepreneurial are architects?" RIBA Journal (April 2005): ii-iv.

Timmons, Jeffry A. and Stephen Spinelli. New venture creation: entrepreneurship for the $21^{\text {st }}$ Century $\left(7^{\text {th }}\right.$ edition). New York: McGraw-Hill Education, 2007.

Turton, Natasha and Mike Herrington. Global entrepreneurship monitor, 2012: South African report. Cape Town: The UCT Centre for Innovation and Entrepreneurship. Graduate School of Business. University of Cape Town, 2012.

Valerio, Alexandria, Brent Parton and Alicia Robb. Entrepreneurship education and training programmes around the world: dimensions for success. Washington: World Bank, 2014.

Vosloo, Chris. "Establishing viable architectural firms." Architecture South Africa, 72 (May/June 2015): 60-64.

Wickham, Phillip A. Strategic entrepreneurship ( $4^{\text {th }}$ Edition). Harlow: Prentice Hall/Pearson Education, 2006. 